\title{
Correction to: MRI nomenclature for musculoskeletal infection
}

\author{
Erin F. Alaia ${ }^{1} \cdot$ Avneesh Chhabra ${ }^{2}$. Claus S. Simpfendorfer ${ }^{3} \cdot$ Micah Cohen $^{4} \cdot$ Douglas N. Mintz $^{5}$. \\ Josephina A. Vossen ${ }^{6} \cdot$ Adam C. Zoga $^{7}$. Jan Fritz ${ }^{1}$. Charles E. Spritzer ${ }^{8}$. David G. Armstrong ${ }^{9} \cdot$ William B. Morrison $^{7}$
}

Published online: 27 January 2022

(c) The Author(s) 2022

\section{Correction to: Skeletal Radiology (2021) 50:2319-2347 https://doi.org/10.1007/s00256-021-03807-7}

The article "MRI nomenclature for musculoskeletal infection", written by Alaia, E.F., Chhabra, A., Simpfendorfer, C.S., Cohen, M., Mintz, D.N., Vossen, J.A., Zoga, A.C., Fritz, J., Spritzer, C.E., Armstrong, D.G., Morrison, W.B., was originally published Online First without Open Access. After publication in volume 50, issue 12, page 2319-2347 the author decided to opt for Open Choice and to make the article an Open Access publication. Therefore, the copyright of the article has been changed to $($ The Author(s) 2022 and the article is forthwith distributed under the terms of the Creative Commons Attribution 4.0 International License, which permits use, sharing, adaptation, distribution and reproduction in any medium or format, as long as you give appropriate

The original article can be found online at https://doi.org/10.1007/ s00256-021-03807-7.

Erin F. Alaia

Erin.Fitzgerald@nyulangone.org

Avneesh Chhabra

avneesh.chhabra@utsouthwestern.edu

Claus S. Simpfendorfer

simpfec2@ccf.org

Micah Cohen

cohenmic@einstein.edu

Douglas N. Mintz

mintzd@hss.edu

Josephina A. Vossen

josephina.vossen@vcuhealth.org

Adam C. Zoga

adam.zoga@jefferson.edu

Jan Fritz

Jan.Fritz@nyulangone.org

Charles E. Spritzer

chuck.spritzer@duke.edu credit to the original author(s) and the source, provide a link to the Creative Commons licence, and indicate if changes were made. The images or other third party material in this article are included in the article's Creative Commons licence, unless indicated otherwise in a credit line to the material. If material is not included in the article's Creative Commons licence and your intended use is not permitted by statutory regulation or exceeds the permitted use, you will need to obtain permission directly from the copyright holder. To view a copy of this licence, visit http://creativecommons.org/licenses/by/4.0. Open access funding enabled and organized by Projekt DEAL.

The original articles has been corrected.

David G. Armstrong

dgarmstr@usc.edu

William B. Morrison

william.morrison@jefferson.edu

1 NYU Langone Medical Center, New York, NY, USA

2 UT Southwestern Medical Center, Dallas, TX, USA

3 Cleveland Clinic, Cleveland, OH, USA

4 Albert Einstein Medical Center, Philadelphia, PA, USA

5 HSS, New York, NY, USA

6 VCU, Richmond, VA, USA

7 Thomas Jefferson University Hospital, Philadelphia, PA, USA

8 Duke University Hospital, Durham, NC, USA

9 Keck Hospital of USC, Los Angeles, CA, USA 
Open Access This article is licensed under a Creative Commons Attribution 4.0 International License, which permits use, sharing, adaptation, distribution and reproduction in any medium or format, as long as you give appropriate credit to the original author(s) and the source, provide a link to the Creative Commons licence, and indicate if changes were made. The images or other third party material in this article are included in the article's Creative Commons licence, unless indicated otherwise in a credit line to the material. If material is not included in the article's Creative Commons licence and your intended use is not permitted by statutory regulation or exceeds the permitted use, you will need to obtain permission directly from the copyright holder. To view a copy of this licence, visit http://creativecommons.org/licenses/by/4.0/.

Publisher's Note Springer Nature remains neutral with regard to jurisdictional claims in published maps and institutional affiliations. 